\title{
LOCALIZATION AND SHAPE OF STENOSES IN CENTRAL LUNG CARCINOMA - SENSITIVITY AND PRECISION OF MDCT VB AND FB
}

\author{
Mitko Atanasov Mitev ${ }^{1}$, Evelin Dosev Obretenov² and Daniel Georgiev Valchev ${ }^{2}$
}

\begin{abstract}
${ }^{1}$ Department of Medical Physics, Biophysics, Roentgenology and Radiology, Faculty of Medicine, Department of Diagnostic Imaging, St. Kirkovich University Hospital, Trakia University-Stara Zagora, Stara Zagora, Bulgaria; ${ }^{2}$ Department of Special Surgery/Thoracic Surgery, Vascular Surgery, Pediatric Surgery and Orthopedics and Traumatology, Faculty of Medicine, Division of Thoracic Surgery, St. Kirkovich University Hospital, Trakia University-Stara Zagora, Stara Zagora, Bulgaria
\end{abstract}

SUMMARY - The objective is to present diagnostic capabilities of virtual bronchoscopy (VB) and fiberoptic bronchoscopy $(\mathrm{FB})$ for determining the localization and shape of stenoses in patients with central lung carcinoma. A systematic study was performed on 220 patients aged 11-83 $(54.36 \pm 17.24)$ years with endobronchial disease using the FB and VB methods during the 2013-2017 period. Central carcinoma of the lung was found on VB in 130 patients and on FB in 120 patients. Other nosologic diseases were found in 22 patients. Right localization of central carcinoma prevailed over left localization in both sexes. A significant difference in the localization criterion was found in female patients examined by VB (U-test, $\mathrm{p}=0.01$ ). $\mathrm{VB}$ and $\mathrm{FB}$ yielded $86.5 \%$ vs. $91.60 \%$ precision and $85 \%$ vs. $94.5 \%$ sensitivity. In conclusion, VB was found to be a successful noninvasive method for determining the localization of lung tumors and shape of stenoses, which are essential in the diagnosis of malignant processes.

Key words: Cancer; Lung; Localization; Virtual bronchoscopy; Fiberoptic bronchoscopy

\section{Introduction}

Lung carcinoma is one of the most common diseases in the world, associated with high mortality and low survival rates. This requires study to be carried out using modern methods and equipment. According to a number of authors ${ }^{1-6}$, with the introduction of low-dose computed tomography (CT) screening, the proportion of diagnosed tumors has grown significantly, and virtual bronchoscopy $(\mathrm{VB})$ is an important prognostic factor for successful bronchoscopy; fiberoptic bronchoscopy

Correspondence to: Chief Assist. Mitko Miter, MD, Department of Medical Physics, Biophysics, Roentgenology and Radiology, Faculty of Medicine, Department of Diagnostic Imaging, St. Kirkovich University Hospital, Trakia University-Stara Zagora, 6000 Stara Zagora, Bulgaria

E-mail: mitev.mitko69@gmail.com

Received October 2, 2018, accepted November 11, 2019
(FB) successfully visualizes the mucosal layer, but does not allow for the evaluation of deep layers or adjacent tissue. VB with multidetector computed tomography (MDCT) is a new noninvasive diagnostic method allowing a three-dimensional image and providing excellent assessment of the wall of the airways ${ }^{7,8}$. The localization and shape of the tumors are of particular importance for the diagnosis, and the type of tumor and subsequent interventions for their treatment ${ }^{8-10}$.

The aim of this study was to present diagnostic capabilities of VB and FB for determining the localization and shape of stenoses in patients with central lung carcinoma.

\section{Patients and Methods}

This study conducted during the 2013-2017 period included 220 patients aged 11 to 83 years that under- 
went VB method with MDCT. Patients had been previously diagnosed with the FB method. Of these, 130 patients were diagnosed with central carcinoma. $\mathrm{Pa}-$ tients were divided into four age groups (Table 1). Twenty-two patients had negative results and were diagnosed with other diseases.

Table 1. Patient distribution according to diagnosis, age and sex

\begin{tabular}{|l|l|l|l|l|}
\hline Diagnosis & \multicolumn{2}{l|}{ Central carcinoma } & \multicolumn{2}{l|}{ Other } \\
\hline $\begin{array}{l}\text { Age group (yrs) } \\
\text { /Sex }\end{array}$ & $\begin{array}{l}\text { Male, } \\
\mathrm{n}\end{array}$ & $\begin{array}{l}\text { Female, } \\
\mathrm{n}\end{array}$ & $\begin{array}{l}\text { Male, } \\
\mathrm{n}\end{array}$ & $\begin{array}{l}\text { Female, } \\
\mathrm{n}\end{array}$ \\
\hline $26-35$ & 1 & 1 & - & 1 \\
\hline $36-55$ & 4 & 4 & 4 & 2 \\
\hline $56-75$ & 69 & 20 & 5 & 4 \\
\hline$>75$ & 4 & 7 & 3 & 3 \\
\hline Total: 152 & 98 & 32 & 12 & 10 \\
\hline
\end{tabular}

Philips Essenca (Philips Medical Systems, Cleveland, Ohio, USA) was used for VB, whereas FB was performed on Olympus BF PE2 (Olympus Corp., Tokyo, Japan) and Fujinon EP-120 T (Fujinon-Fujifilm Corp., Saitama, Japan). The VB study was conducted using MDCT Philips Essenca and 64 MDCT Siemens Definition AS (Siemens Aktiengesellschaft, Munich, Germany). Studies were performed with optimized standard protocols by using different slice thickness, current strength, voltage, etc. Scanning was done with breath holding for about 10 seconds, automatically adjusted, with contrast enhancement or natively. Multiplanar reconstructions were carried out using maximum intensity projection techniques and capabilities for archiving and exporting images and video.

The following criteria for pathological changes were considered in the work: localization of the lesion (left or right, peripheral or central); and shape of the lesion.

In order to compare the results of FB and VB, sensitivity and precision indicators were determined. Sensitivity is calculated by the ratio: sensitivity $=$ true-positive/false-negative + true-positive. Precision is determined by the ratio: precision $(\%)=100 \times$ (true-positive + true-negative/true-positive + false-positive + truenegative + false-negative). True-positive are the cases identified with anomalies by both methods. True-negative are the cases identified without anomalies by FB and VB. False-positive are those identified with anomalies by VB but without anomalies by FB. False-negative are the cases identified without anomalies by VB but with anomalies by FB.

\section{Statistical analysis}

The significance of changes was assessed by the non-parametric tests, i.e. Man-Whitney test (U-test) and Kruskal-Wallis test (H-test). In all cases of variation in the values of the compared criteria, rank and mean \pm SD were defined. The software products MS Excel (Microsoft 2010), BioDiversity Pro and Statistica 10 were used on statistical data processing ${ }^{11,12}$.

\section{Results}

In the total of 220 study patients with lung carcinoma, central carcinoma was found on $\mathrm{VB}$ in 130 (59.09\%) patients, $98(75.38 \%)$ male and $32(24.62 \%)$ female. On FB, 120 out of 220 (54.55\%) patients were diagnosed with central carcinoma, 89 (74.17\%) male and $31(25.83 \%)$ female. Thus, there were no significant differences (H-test, $\mathrm{p}>0.05)$ between the number of patients of both sexes and their incidence (\%) tested by FB and VB (Fig. 1).

Twenty-two (8.12\%) patients were diagnosed with other nosologic diseases, $12(54.55 \%)$ male and 10

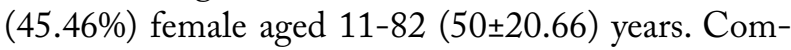
pared to the total number of patients studied, the inci-

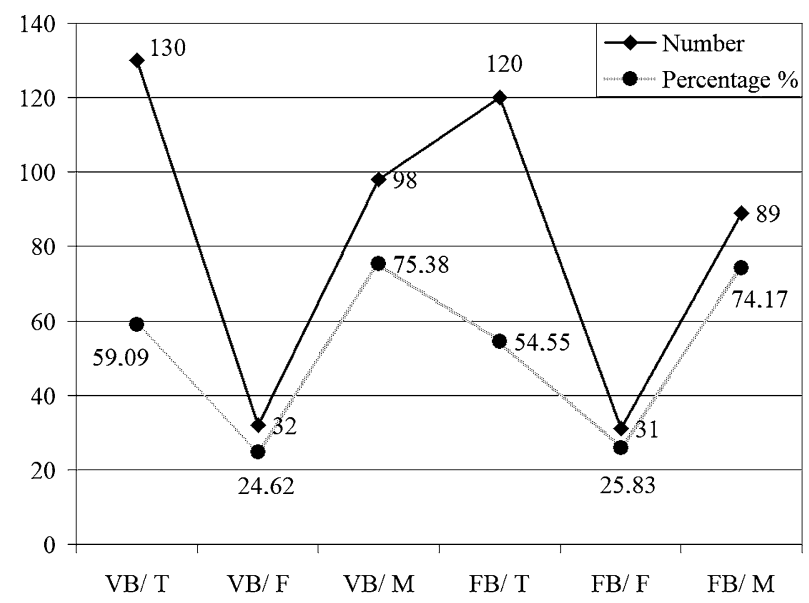

Fig. 1. Number and prevalence (\%) of patients with central carcinoma studied by $V B$ and $F B$.

$\mathrm{VB}=$ virtual bronchoscopy $\mathrm{FB}=$ fiberoptic bronchoscopy $; \mathrm{T}=$ total number of patients; $F$ = female; $M=$ male 
dence rate was $4.43 \%$ in male and $3.69 \%$ in female pateints.

\section{Localization}

According to the VB results, central carcinoma with right localization predominated in male patients $(\mathrm{n}=52 ; 53.06 \%)$ compared to those with left localization ( $\mathrm{n}=46 ; 46.94 \%)$ (Fig. 2). However, the observed difference in the number of male patients with central carcinoma according to localization and their prevalence was not significant (U-test, $\mathrm{p}=0.39$ ).

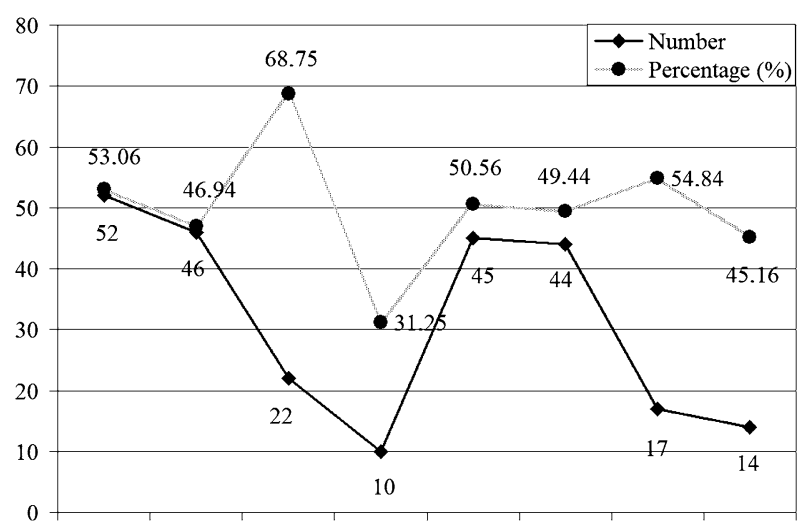

VB M/R VB M/L VB F/R VB F/L FB M/R FB M/L FB F/R FB F/L

Fig. 2. Number and prevalence (\%) of patients with central carcinoma according to sex and localization.

$\mathrm{VB}=$ virtual bronchoscopy; $\mathrm{FB}$ = fiberoptic bronchoscopy; $\mathrm{M}=$ male; $\mathrm{F}$ = female; $\mathrm{R}$ = right; $\mathrm{L}=$ left

The male patients with right localized central carcinoma studied by VB were mainly from the $56-75$ age group $(\mathrm{n}=35 ; 35.71 \%)$, followed by patients from the $>75$ age group $(n=9 ; 9.18 \%)$ and $36-55$ age group $(n=8$; $8.16 \%)$. None of the patients from the $26-35$ age group had right localized central carcinoma. Among the patients from the 56-75 age group, the number of male patients aged over 60 was largest. According to the results of the FB examination, the majority of patients had right localization of central carcinoma $(n=45$; $50.56 \%$ ). On both FB and VB, patients in the 56-75 age group predominated, followed by those in the $>75$ and $36-55$ age groups.

By using VB, central left carcinoma was diagnosed in $34(34.7 \%)$ male patients from the 56-75 age group, six $(6.13 \%)$ male patients from the $36-55$ age group and five $(5.10 \%)$ male patients from the $>75$ age group. Patients in the 56-75 age group were mainly aged 60-
62 , those from the 36-55 age group were aged 56-59 years, and those from the $>75$ age group were aged $>78$. The 26-35 age group was represented by one (1.02\%) patient aged 33. The FB performed on 44 male patients with central left carcinoma showed results that followed the tendency presented upon VB on the predominance of patients from the 56-75 age group.

The VB performed on female patients showed the prevalence of right central carcinoma, the number of patients being 2.2 -fold greater $(n=22 ; 64.71 \%)$ than the number of female patients diagnosed with left central carcinoma $(n=10 ; 29.41 \%)$. On VB, significant left-and-right localization differences were found in the number and prevalence of the female patients with central carcinoma (U-test, $\mathrm{p}=0.01$ ). Female patients diagnosed with right localized central carcinoma by VB were again mainly from the 56-75 age group (15 women aged $>60$ years; $46.88 \%$ ), followed by the $36-$ 55 and $>75$ age groups with the same number of patients (three women both; $9.38 \%$ ) and one (3.12\%) patient in the 26-35 age group. Using FB, 17 (54.84\%) female patients were diagnosed with right central carcinoma (Fig. 2). The trend for the largest number of patients in the 56-75 age group was maintained, followed by the 36-55 and $>75$ age groups. According to VB results, among female patients with left central carcinoma, those in the 56-75 age group predominated with five $(15.63 \%)$ patients, followed by the $>75$ age group $(n=4 ; 12.5 \%)$ and $36-55$ age group $(n=1 ; 3.12 \%)$. There were no female patients from the 26-35 age group. The trend of the largest number of patients from the 56-75 group, over 60 years of age, was maintained. According to FB results, 14 (45.16\%) female patients from the 56-75 age group had left central carcinoma (Fig. 2).

\section{Shape of lesions}

Computed tomography characteristics of the lesions vary depending on the type of carcinoma and its localization. Carcinomas have varying degrees of blood supply, hypervascularized or hypovascularized. Both focal lesions and lesions with diffuse spread have been identified. Depending on the growth in or out of the bronchus, the lesions may be exobronchial, endobronchial and mixed. Focal lesions are of different shapes, dimensions and outlines, homogeneous hyperdense structure or inhomogeneous heterogeneous structure. 


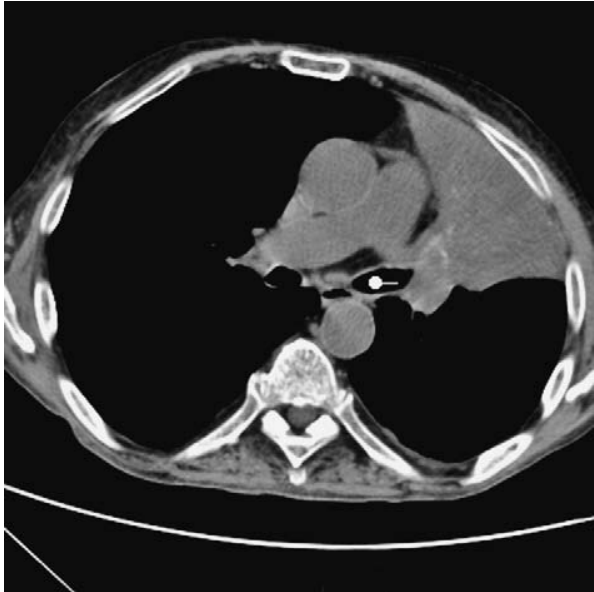

Fig. 3. Atelectasis from obstruction of bronchus by computed tomography.

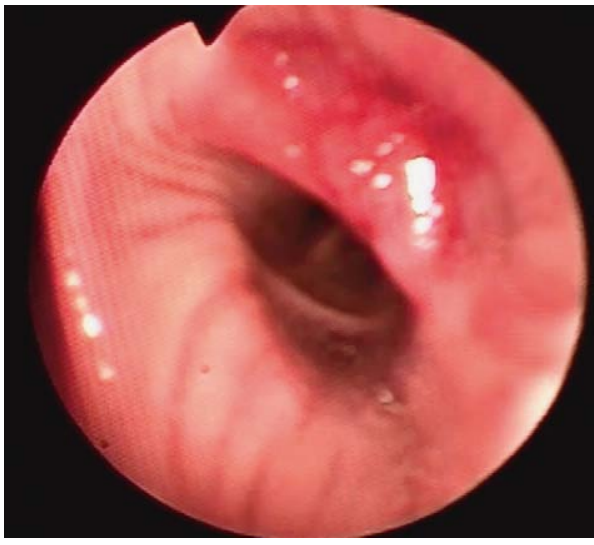

Fig. 4. Stenosis and deformation of bronchus by fiberoptic bronchoscopy.

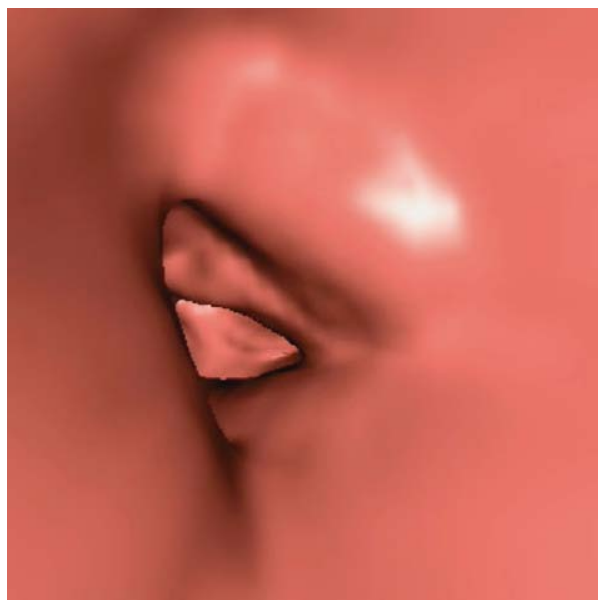

Fig. 5. Stenosis and deformation of bronchus by virtual bronchoscopy.

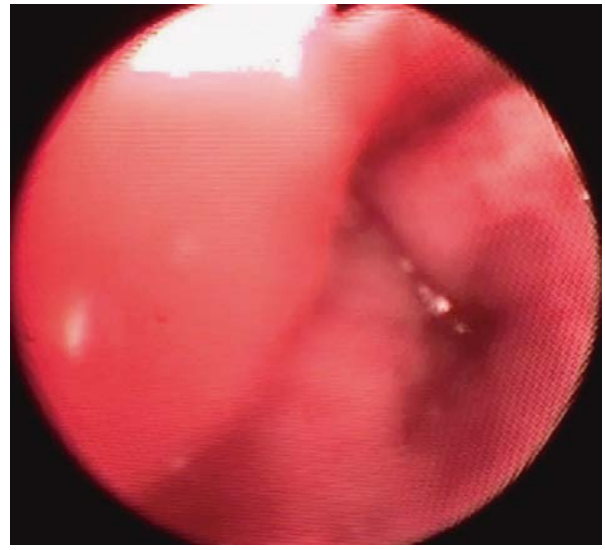

Fig. 6. Obturation of bronchus by fiberoptic bronchoscopy.

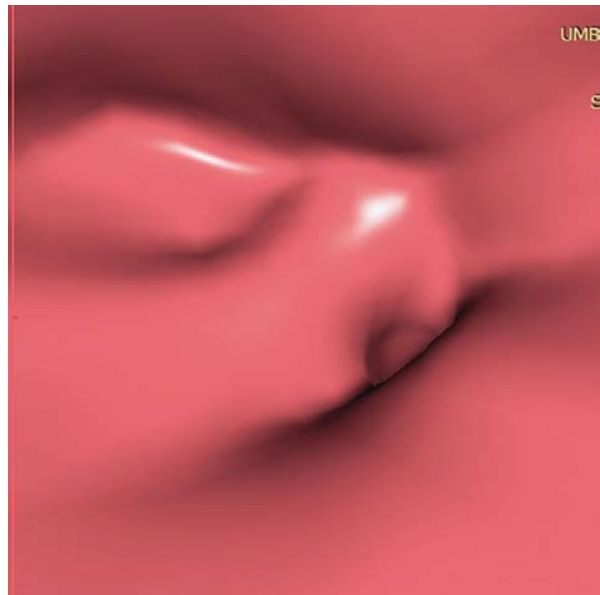

Fig. 7. Obturation of bronchus by virtual bronchoscopy.

All these differences were also diagnosed in the postprocessing VB performed in this study. Round and oval lesions that do not infiltrate the bronchus give a regular sharp arc defect of compression. Those of polygonal shape give wavy defects of impression, and lesions with polycyclic outlines and spicules, infiltrating the wall, give changes irregular by shape, mostly with polycyclic outlines. The lesions of irregular shape also cause changes with an irregular wall and lumen defect, most of which are with infiltration and disturb the correct linearity of the bronchus contour. Such findings change the size of the lumen and, in some cases, the normal shape of the bronchi. Depending on the size of the lesion, in most cases more than one bronchus is affected. Endobronchial lesions, although small 
(up to a few millimeters), lead to rapid stenosis and bronchial obstruction. The large exobronchially located formations compress, dislocate, can infiltrate and also obliterate the bronchi, but more slowly and at a later stage in their development. CT manifestations of the changes show modifications also in the pulmonary parenchyma in high-grade stenoses and obturations with distal hypoventilation and atelectasis. The $\mathrm{CT}$ dimensions of carcinomas range from 2-3 to 7-8 (5 \pm 2.16$)$ $\mathrm{cm}$. Exobronchial processes usually cause slower stenoses and occlusions as a result of provoked external compression. Endobronchial neoplasia usually grows as intraluminal and extraluminal formation, causing faster bronchial stenoses and obturations. As a result of the changes, irregular intraluminal shapes, usually originating from the wall, located on a broad base and forming an obtuse or other angle with it, are seen. Changes in lumen can occur as a result of endobronchial disseminations giving various intraluminal defects. Lymphogenic disseminations, when coming from a single lymph node, cause a regular arc defect; when coming from multiple lymph nodes, they cause lobular defects of external compression with the presence of varying degrees of lumen stenosis. Subcarinal lymph nodes and adjoining formations cause deformation of the carina and disturb the angle of the carina (Figs. 3-7).

Twenty-two false-positive results were recorded due to bronchial secretions, pleural effusions, infiltrative inflammatory changes, and other diseases beyond the described ones, which also showed a defect in the lumen, of varying shape and size, causing stenosis in the intraluminal space.

\section{Discussion}

According to the results of the study, the prevalence of patients with right central carcinoma diagnosed on VB was greater than that obtained on FB in both sexes. The prevalence of both left and right central carcinoma was higher in male than in female patients. The number of patients from the 56-75 age group, over 60 years of age, was highest in both male and female patients. Similar trends were also seen in the results obtained with FB.

Difference in the number of patients (male and female) diagnosed by using VB and FB was small. A greater number of female patients were diagnosed with left central carcinoma, with an increase in their number on VB. Eleven patients with central carcinoma were reported as peripheral after using FB. On VB, four patients with right central carcinoma (three male and one female) were diagnosed as peripheral, and seven of those with left central carcinoma (six male and one female) were diagnosed as left peripheral carcinomas. No statistically significant differences were found in the results obtained by the two methods according to the localization criteria (H-test, $\mathrm{p}=0.05$ ).

$\mathrm{Li}$ et al. determined the type of lymph node and tumor (malignant or benign) according to morphological CT characteristics9. Round and oval lesions, which have a hypodense central part, usually are predominantly malignant. Round lesions with smooth and sharp outlines and homogeneous structure also show a high degree of malignancy. Solid nodules with a polygonal shape and presence of hyperdense, gentle or pronounced irregular spicules, show a high prevalence of malignancy. Lesions that do not have a regular shape and sharp outlines are also reported to be malignant in a large proportion of cases. There are many cases of lymph nodes with polygonal shape related to benign processes. Normally, sharp outlines are more common in benign changes, and those with non-sharp, irregular outlines, with the presence of small fine or pronounced spicules, are often of a malignant nature.

In $90 \%$ of the patients with right central carcinoma from the present study, the shape was oval, irregularly lobulated, and in $10 \%$ it was only oval, with cases of lumen obliteration. All changes in right central carcinoma are associated with lumen stenoses due to endoor exobronchial processes. Stenoses from external compression of the lumen predominate over those from internal compression. On both $\mathrm{VB}$ and $\mathrm{FB}$, the shape of changes in both sexes is expressed in oval, lobular, polycyclic defects forming a different angle with the wall, protruding intra- or extraluminally, with concentric or eccentric tracheobronchial tree stenoses or complete obliteration. The contours may be smooth or uneven and irregular. In left central and right localized carcinomas, the lobule defects and stenoses predominate over those with full lumen obliteration. In peripheral carcinomas, stenotic changes and obliterations predominate in both sexes. Indirectly, by the magnitude of changes in bronchus, the magnitude of the process can be judged compared to $\mathrm{CT}$ with axial and multiplanar reconstructions, which plays an im- 
portant role in determining the stage of the finding and the correct behavior towards the TNM stage, which could be the subject of future studies.

Impairment of the regular shape with the presence of a wavy defect in the bronchus lumen was found on $\mathrm{VB}$, causing one or several irregular stenoses or multiarc changes in the lumen, irregular stenosis of the lumen with partial or complete obstruction. In some patients, the disease was accompanied by mediastinal bronchial and bronchopulmonary lymphadenomegaly. On VB it was depicted as a single or multi-arc compression of the wall, altering the shape and causing partial stenosis of the lumen, as well as smoothing of the trachea and deleting the cartilages.

According to $\mathrm{Li}$ et al., the oval findings with smooth shape indicate a malignant process or significantly increased lymph nodes 9 . Those with unequal irregular outlines, multiple polycyclic changes, protruding unevenly to the lumen, are characteristic of malignant aggressive processes leading to infiltration of adjacent structures. Thus indirectly targeted, the changes help determine the stage and behavior for choosing the treatment, intervention or surgery. Greater spatial clarity is always achieved in combination with axial and multiplanar images.

Results of the studies carried out were similar to those of FB. In some patients undergoing real bronchoscopy, changes were not found, or changes were observed as a result of lymphadenomegaly. In the cases of extrabronchial tumor formations as a result of external tracheal and bronchial compression and impression, no differentiation could be made either it being a tumor process or lymph node packs.

Advantage of the proposed study carried out with 64-slice MDCT and comparison of VB and FB results was an increase in the precision percent of neoplasm localization, their size, degree of stenosis, as well as prestenotic and poststenotic processes. In the present study, precision (success rate) of the VB in the diagnosis of central carcinoma was $86.5 \%$ of the cases compared to $91.60 \%$ reported for FB. The sensitivity achieved by VB and $\mathrm{FB}$ was $85 \%$ and $94.5 \%$, respectively. Better success rate in favor of FB was established, the difference being minimal. The identified differences were due to the higher number of falsenegative results reported for VB.

Besides good visualization of the central airways recorded in our study ( $90 \%$ of cases), a high rate of success was achieved by Summers et al., Allah et al. and Ferretti et al. with $94.2 \%$ success rate in central lung lesions ${ }^{13-15}$. Good diagnostic quality (95\%) for stenotic changes was achieved by Fleiter et al., but lower (75\%) success rate than ours in cases of impression-induced lesions ${ }^{16}$. Similar to our results in case of endoluminal lesions were achieved by Finkelstein et al. ${ }^{17}$. Horton $e t$ al. report comparably high results in tracheobronchial tree visualization using $64 \mathrm{MDCT}^{18}$.

Very high sensitivity (100\%) and specificity (87.5\%) in central carcinomas were achieved by Gagov ${ }^{19}$. The precision of the method used by Gagov reached $96.8 \%$ using specific protocols for children and adults ${ }^{19}$. Radwan-Röhrenschef and Burakowska found higher specificity of the method (95.5\%) in central carcinomas and sensitivity of $79.5 \%{ }^{20}$.

Lower results than ours for single-bronchus located lesions have been reported by Ece et al. (56\% sensitivity $)^{21}$. Low sensitivity due to granulations, synechiae and others (60\% success rate) have been published by Joshi et al. ${ }^{22}$ and Maniatis et al. ${ }^{23}$. Significantly lower success rate was also achieved by Sundarakumar et al. ( $45 \%$ success rate reported by the team as unfavorable for accurate diagnostics, etc. $)^{24}$.

In conclusion, according to the results obtained by both methods in both sexes, the right localization prevailed over the left one in central carcinoma. A significant difference in the localization criterion was found in female patients under study by VB (U-test, $p=0.01$ ). No statistically significant differences were found in the prevalence in both sexes concerning the localization when comparing the results of both methods. In left central and right localized carcinomas, the lobular defects and stenoses predominated over those with full lumbar obliteration. The 56-75 age group was shown to have the most serious changes by both methods in patients diagnosed with carcinomas of both sexes. As a result of changes from nosologic diseases different from those in the present study, VB could find its place in the screening study of a number of chronic lung diseases such as chronic obstructive pulmonary disease, pulmofibrosis, etc. A disadvantage of the methodology is that it can determine changes in the mucosa in surface injuries.

\section{References}

1. Naidich DP, Sussman R, Kutcher WL, Aranda CP, Garay SM, Ettenger NA. Solitary pulmonary nodules. CT-bronchoscopic 
correlation. Chest. 1988;93:595-8. https://doi.org/10.1378/ chest.93.3.595

2. Nakai T, Matsumoto Y, Suzuk F, Tsuchida T, Izumo T. Predictive factors for a successful diagnostic bronchoscopy of ground-glass nodules. Ann Thorac Med. 2017;12(3):171-6. doi: 10.4103/atm.ATM_428_16

3. Nardelli P, Jaeger A, O'Shea C, Khan KA, Kennedy MP, Cantillon-Murphy P. Pre-clinical validation of virtual bronchoscopy using 3D slicer. Int J Comput Assist Radiol Surg. 2017; 12(1):25-38. https://doi.org/10.1007/s11548-016-1447-7

4. Church TR, Black WC, Aberle DR, Berg CD, Clingan KL, Duan F, et al. Results of initial low-dose computed tomographic screening for lung cancer. N Engl J Med. 2013;368:1980-91. doi: 10.1056/NEJMoa1209120

5. Rivera MP, Mehta AC, Wahidi MM. Establishing the Diagnosis of Lung Cancer: Diagnosis and Management of Lung Cancer, $3^{\text {rd }}$ edn. American College of Chest Physicians evidencebased clinical practice guidelines. Chest. 2013;143(5):e142S165S. https://doi.org/10.1378/chest.12-2353

6. Minezawa T, Okamura T, Yatsuya H, Yamamoto N, Morikawa $\mathrm{S}$, Yamaguchi T, et al. Bronchus sign on thin-section computed tomography is a powerful predictive factor for successful transbronchial biopsy using endobronchial ultrasound with a guide sheath for small peripheral lung lesions: a retrospective observational study. BMC Med Imaging. 2015;15:21. https://doi. org/10.1186/s12880-015-0060-5

7. Barnes D, Chacoff J, Benegas M, Perea R, Caralt T, Ramirez $\mathrm{J}$, et al. Central airway pathology: clinic features, CT findings with pathologic and virtual endoscopy correlation. Insights Imaging. 2017;8:255-70. https://doi.org/10.1007/s13 244-017-0545-6

8. Mitev MA. Virtual bronchoscopy with Multidetector Computer Tomography. Doctoral dissertation. Stara Zagora: Trakia University, 2017;180.

9. Li F, Sone Sh, Abe H, MacMahon H, Doi K. Malignant versus benign nodules at $\mathrm{CT}$ screening for lung cancer: Comparison of thin-section CT findings. Radiology. 2004;233:793-8. https: //doi.org/10.1148/radiol.2333031018

10. Luo M, Duan Ch, Qiu J, Li W, Zhu D, Cai W. Diagnostic value of multidetector $\mathrm{CT}$ and its multiplanar reformation, volume rendering and virtual bronchoscopy postprocessing techniques for primary trachea and main bronchus tumors. PLoS One. 2015;10(9):e0137329. https://doi.org/10.1371/journal. pone. 0137329

11. McAleece N, Gage JDG, Lambshead PJD, Peterson GLJ. BioDiversity Professional Statistics Analysis Software. London: Scottish Association for Marine Science and Natural History Museum, 1997. http://www.sams.ac.uk.

12. StatSoft Inc., 2011. STATISTICA (data analysis software system), version 10. www.statsoft.com.

13. Summers RM, Feng DH, Holland SM, Shelhamer JH. Virtual bronchoscopy: segmentation method for real-time display. $\mathrm{Ra}-$ diology. 1996;200(3):857-62. https://doi.org/10.1148/radiology.200.3.8756944

14. Allah MF, Hussein SR, El-Asmar AB, Zoair HM, Mohamed GA, Metwaly AM, et al. Role of virtual bronchoscopy in the evaluation of bronchial lesions. J Comput Assist Tomogr. 2012;36(1):94-9. doi: 10.1097/RCT.0b013e31824443b2

15. Ferretti GR, Knoplioch J, Bricault I, Brambilla Ch, Coulomb M. Central airway stenoses: preliminary results of spiral-CTgenerated virtual bronchoscopy simulations in 29 patients. Eur Radiol.1997;7:854-9.https://doi.org/10.1007/s003300050218

16. Fleiter T, Merkle EM, Aschoff AJ, Lang G, Stein M, Görich J, et al. Comparison of real-time virtual and fiberoptic bronchoscopy in patients with bronchial carcinoma: opportunities and limitations. AJR Am J Roentgenol. 1997;169(6):1591-5. doi: 10.2214/ajr.169.6.9393172

17. Finkelstein SE, Schrump DS, Nguyen DM, Hewitt SM, Kunst TF, Summers RM. Comparative evaluation of super high-resolution CT scan and virtual bronchoscopy for the detection of tracheobronchial malignancies. Chest. 2003;124(5):1834-40. https://doi.org/10.1378/chest.124.5.1834

18. Horton KM, Horton MR, Fishman EK. Advanced visualization of airways with 64-MDCT: 3D mapping and virtual bronchoscopy. AJR Am J Roentgenol. 2007;189:1387-96. doi: 10.2214/AJR.07.2824

19. Gagov EG. Multidetector computer-tomographically-generated virtual bronchoscopy. Doctoral dissertation. Sofia: Clinic on Imaging Diagnostics, University Hospital NI Pirogov, 2016;121.

20. Radwan-Röhrenschef P, Burakowska B. Virtual bronchoscopy versus bronchofiberoscopy - a comparison of diagnostic value in assessment of central lung tumours. Pneumonol Alergol Pol. 2003;80(2):127-39.

21. Ece F, Çiðdem P, Meltem T, Reha B, Ali YM, Atadan T. Comparison of the results obtained with spiral computerized tomography and fiberoptic bronchoscopy of the airways of lung cancer patients. Turk Respir J. 2000;1(2):6-10.

22. Joshi AR, Khanna PC, Merchant SA, Khandelwal A, Agrawal N, Karnik ND. Role of multidetector CT virtual bronchoscopy in the evaluation of post-tracheostomy tracheal stenosis - a preliminary study. J Assoc Physicians India. 2003;51:871-6.

23. Maniatis PN, Triantopoulou CC, Tsalafoutas IA, Lamprakis CK, Malagari KS, Konstantinou K, et al. Virtual bronchoscopy versus thin section computed tomography in evaluation of moderate and low grade stenoses: receiver operating characteristic curve analysis. Acta Radiol. 2006;47(1):48-57. https://doi. org/10.1080/02841850500406837

24. Sundarakumar DK, Bhalla AS, Sharma R, Hari S, Guleria R, Khilnani G. Multidetector CT evaluation of central airways stenoses: comparison of virtual bronchoscopy, minimal-intensity projection, and multiplanar reformatted images. Indian J Radiol Imaging. 2011;21(3):191-4. doi: 10.4103/0971-3026. 85366 
Sažetak

\section{LOKALIZACIJA I OBLIK STENOZA U CENTRALNOM KARCINOMU PLUĆA - OSJETLJIVOST I PRECIZNOST MDCT VB I FB}

\section{Atanasov Miter, E. Dosev Obretenov i D. Georgiev Valchev}

Cilj je prikazati dijagnostičke mogućnosti virtualne bronhoskopije $(\mathrm{VB})$ i fiberoptičke bronhoskopije (FB) za određivanje lokalizacije i oblika stenoze u bolesnika sa središnjim karcinomom pluća. Sustavna studija provedena je na 220 bolesnika u dobi od 11 do 83 godine $(54,36 \pm 17,24)$ s endobronhijalnom bolesti primjenom metoda FB i VB u razdoblju od 2013. do 2017. godine. Središnji karcinom pluća otkriven je na VB u 130 bolesnika i na FB u 120 bolesnika. U 22 bolesnika pronađene su druge nozološke bolesti u oba spola. Desnostrana lokalizacija prevladavala je nad lijevostranom lokalizacijom središnjeg karcinoma. Značajna razlika u kriteriju lokalizacije pronađena je u žena koje su pregledane pomoću VB (U-test, $\mathrm{p}=0,01$ ). Preciznost VB bila je $86,5 \%$ prema $91,60 \%$ za FB, dok je osjetljivost VB bila $85 \%$ u usporedbi s $94,5 \%$ za FB. Zaključeno je da je VB uspješna neinvazivna metoda za određivanje lokalizacije tumora pluća i oblika stenoza, koji su neophodni u dijagnostici zloćudnih procesa.

Ključne riječi: Rak; Pluća; Lokalizacija; Virtualna bronhoskopija; Fiberoptička bronhoskopija 